\title{
ANALISIS FAKTOR YANG BERHUBUNGAN DENGAN KEJADIAN SEPSIS NEONATORUM DI RUANG PERINATOLOGI RSUD DR. H. ABDUL MOELOEK PROVINSI LAMPUNG
}

\author{
Yessy Rachmawati ${ }^{1}$ \\ ${ }^{1}$ Perawat RSUD DR. Abdul Moeloek \\ Email: yessyrw@gmail.com
}

\begin{abstract}
ANALYSIS OF FACTORS RELATING TO THE EVENT OF NEONATORUM SEPSIS IN THE PERINATOLOGY ROOM RSUD DR. H. ABDUL MOELOEK LAMPUNG PROVINCE
\end{abstract}

Background : Maternal and child health problems are national problems that need to get top priority because they determine the quality of human resources in future generations. Children, especially infants, are more susceptible to diseases and unhealthy living conditions. Therefore, various efforts have been made by various parties to improve the health of infants, especially infants during the perinatal period (Ministry of Health Republic of Indonesia, 2018). Based on data from Dr. RSUD's medical records H. Abdul Moeloek from 2017 - 2019 saw an increase in the incidence of Neonatal sepsis in the Regional General Hospital (RSUD) Dr. H. Abdul Moeloek, where in 2017 there were 193 incidents, in 2018 there were 242 incidents and in 2019 there were 317 sepsis neonatorum incidents.

Purpose : to find out the factors related to the occurrence of Sepsis Neonatorum in the Perinatology Room of RSUD Dr. H. Abdul Moeloek Lampung Province in 2020.

Methods : This type of quantitative analytic research with a case control approach, the subjects in this study were all babies born in 2019 in RSUD Dr. H. Abdul Moeloek Lampung Province in 2020. The object of the study was the incidence of Sepsis Neonatorum, premature rupture of membranes, infection during pregnancy, LBW, and the sex of the baby. The research will be carried out after the proposal is approved.

Result : It is known that out of 178 respondents, $144(80.9 \%)$ of respondents did not have sepsis neonatorum, most of the respondents were $113(63.5 \%)$ without PROM, most of the respondents had no infection as much as 158 (88.8\%). Most of the respondents who were LBW were 99 (55.6\%). There is a relationship between premature rupture of membranes and Sepsis Neonatorum in the Perinatology room of Dr. H. Abdul Moeloek, Lampung Province, ( $p$ value 0,000 OR 17,400) There is a relationship between infection during pregnancy and Sepsis Neonatorum in the Perinatology room of Dr. H. Abdul Moeloek, Lampung Province, ( $p$ value 0.001 OR 5,583). There is a relationship between LBW and Sepsis Neonatorum in the Perinatology room Dr. H. Abdul Moeloek, Lampung Province, ( $p$ value 0, 0040R 3.857). Suggestions for health workers to improve their capacity in providing health promotion regarding the treatment of Sepsis Neonatorum

Keywords : Neonatal Sepsis, premature rupture of membranes, infection during pregnancy, LBW 
INTISARI: ANALISIS FAKTOR-FAKTOR YANG BERHUBUNGAN DENGAN KEJADIAN SEPSIS NEONATORUM DI RUANG PERINATOLOGI RSUD DR. H. ABDUL MOELOEK PROVINSI LAMPUNG TAHUN 2020

Latar Belakang: Masalah kesehatan ibu dan anak merupakan masalah nasional yang perlu mendapat prioritas utama karena sangat menentukan kualitas sumber daya manusia pada generasi yang mendatang. Anak terutama bayi, lebih rentan terhadap penyakit dan kondisi hidup yang tidak sehat. Oleh sebab itu, dilakukan berbagai upaya oleh berbagai pihak untuk meningkatkan kesehatan bayi, terutama bayi pada masa perinatal (Kemenkes RI, 2018). Berdasarkan Data Rekam medis RSUD Dr. H. Abdul Moeloek dari tahun 2017 - 2019 terlihat peningkatan kejadian sepsis Neonatorum di Rumah Sakit Umum Daerah (RSUD) Dr. H. Abdul Moeloek, dimana tahun 2017 terdapat 193 kejadian, di tahun 2018 terdapat 242 kejadian dan di tahun 2019 terdapat 317 kejadian sepsis neonatorum.

Tujuan Penelitian : untuk mengetahui faktor-faktor yang berhubungan dengan kejadian Sepsis Neonatorum di ruang Perinatologi RSUD Dr. H. Abdul Moeloek Provinsi Lampung tahun 2020.

Metode Penelitian : Jenis penelitian analitik kuantitatif dengan pendekatan cros sectional, subjek dalam penelitian ini adalah seluruh bayi yang lahir di tahun 2019 di RSUD Dr. H. Abdul Moeloek Provinsi Lampung tahun 2020. Obyek dalam penelitian adalah kejadian Sepsis Neonatorum, ketuban pecah dini, infeksi saat hamil, BBLR, dan Jenis kelamin bayi. Penelitian akan dilaksanakan setelah proposal disetujui.

Hasil Penelitian : Diketahui bahwa dari 178 responden, sebanyak 144 (80,9\%) responden tidak Sepsis neonatorum, sebagian besar responden Tidak KPD sebanyak $113(63,5 \%)$, sebagian besar responden tidak ada infeksi sebanyak 158 (88,8\%). Sebagian besar responden BBLR sebanyak 99 (55,6\%). Ada hubungan ketuban pecah dini ( $p$ value 0,000 OR 17,400) Ada hubungan infeksi ( $p$ value 0,001 OR 5,583). Ada hubungan BBLR ( $p$ value $0,0040 R$ 3,857) dengan Sepsis Neonatorum di ruang Perinatologi RSUD Dr. H. Abdul Moeloek Provinsi Lampung tahun 2020. Saran tenaga kesehatan untuk meningkatkan kemampuan dalam pemberian promosi kesehatan mengenai penanganan Sepsis Neonatorum

Kata kunci : Sepsis Neonatorum, ketuban pecah dini, infeksi saat hamil, BBLR

\section{PENDAHULUAN}

Masalah kesehatan ibu dan anak merupakan masalah nasional yang perlu mendapat prioritas utama karena sangat menentukan kualitas sumber daya manusia pada generasi yang mendatang. Anak terutama bayi, lebih rentan terhadap penyakit dan kondisi hidup yang tidak sehat. Oleh sebab itu, dilakukan berbagai upaya oleh berbagai pihak untuk meningkatkan kesehatan bayi, terutama bayi pada masa perinatal (Kemenkes RI, 2018).
Sepsis neonatorum sebagai salah satu bentuk penyakit infeksi pada neonatus masih merupakan masalah utama yang belum dapat terpecahkan sampai saat ini. Sepsis neonatorum adalah Systemic Inflammation Respons Syndrome (SIRS) yang disertai dengan infeksi yang telah terbukti (proven infection) atau tersangka (suspected infection) yang terjadi pada bayi dalam satu bulan pertama kehidupan. SIRS merupakan masa inflamasi yang diawali oleh respon 
host terhadap faktor infeksi dan bukan infeksi berupa suhu, denyut jantung, respirasi dan jumlah leukosit (Rahmawati, 2016).

Hasil Survei Demografi dan Kesehatan Indonesia (SDKI) tahun 2017 menunjukkan AKN sebesar 15 per 1.000 kelahiran hidup, AKB 24 per 1.000 kelahiran hidup, dan AKABA 32 per 1.000 kelahiran hidup. Angka Kematian Balita telah mencapai Target Pembangunan Berkelanjutan (TPB/SDGs) 2030 yaitu sebesar 25/1.000 kelahiran hidup dan diharapkan AKN juga dapat mencapai target yaitu 12/1.000 kelahiran hidup. (Kemenkes RI, 2019).

Kematian Maternal terjadi paling banyak pada periode persalinan dan 24 jam pertama pasca persalinan dan pada masa nifas 8-42 hari. Setiap hari, 830 ibu di dunia, dan di Indonesia 38 ibu, berdasarkan AKI 305 meninggal akibat penyakit/komplikasi terkait kehamilan dan persalinan (WHO, 2019). Sedangkan kematian neonatal terjadi paling banyak pada 24 jam pertama pasca lahir, dan pada masa 2-7 hari pasca lahir (Achadi, 2019). Sebanyak 7000 Bayi baru lahir di dunia meninggal setiap harinya (Indonesia : 185/hari, dg AKN 15/1000 Kel Hidup) Tiga perempat kematian neonatal terjadi pada minggu pertama, dan 40\% meninggal dalam 24 jam pertama Kematian neonatal berkaitan erat dengan kualitas pelayanan persalinan, dan penanganan BBL yg kurang optimal segera setelah lahir dan beberapa hari pertama setelah lahir. Penyebab utama kematian pada tahun 2016 adalah prematur, komplikasi terkait persalinan (asfixia atau kesulitan bernafas saat lahir), infeksi dan cacat lahir (birth defect) (WHO, 2019).

Angka kejadian /insiden sepsis di negara berkembang masih cukup tinggi (1,8 - 18/1000) dibandingkan dengan negara maju (1 - 5/1000 kelahiran). Pada bayi laki-laki resiko sepsis 2 kali lebih besar dari bayi perempuan. Kejadian sepsis juga meningkat pada BKB dan BBLR. Pada bayi berat lahir amat rendah. Secara statistik menunjukkan $90 \%$ kejadian BBLR didapatkan di negara berkembang dan angka kematiannya 35 kali lebih tinggi dibandingkan dengan bayi dengan berat lahir lebih dari 2500 gram. BBLR termasuk faktor utama dalam peningkatan mortalitas, morbiditas dan disabilitas neonatus, bayi dan anak serta memberikan dampak jangka panjang terhadap kehidupannya dimasa depan ( Azzahroh, 2018)

Kejadian sepsis dipengaruhi oleh berbagai faktor seperti faktor ibu (kelahiran kurang bulan, persalinan dengan tindakan, demam pada ibu), faktor lingkungan, serta yang paling penting faktor dari neonatus sendiri, seperti jenis kelamin, status kembar, prosedur invasif, bayi kurang bulan dan berat badan lahir (Manuaba, 2014). Faktor risiko terjadinya sepsis adalah bayi dengan jenis kelamin laki-laki, karena aktivitas pada bayi laki-laki lebih tinggi dibandingkan bayi perempuan sehingga bayi laki-laki memerlukan oksigen yang lebih banyak, karena jika oksigen kurang di dalam tubuh maka bakteri anaerob akan mudah berkembang. Status kembar juga merupakan salah satu faktor risiko, karena bayi kembar kemungkinan besar akan lahir dengan Berat Badan Lahir Rendah (BBLR) dan prematuritas, sehingga akan berisiko mengalami sepsis karena organ tubuhnya belum sempurna dan sistem imunnya kurang yang menyebabkan mudah terkena infeksi.

Menurut Sukarni (2014) fakor risiko yang berhubungan dengan sepsis neonatorum yaitu potensial infeksi (KPD, infeksi saat hamil, amnionitis, prematuritas, dan persalinan tidak steril), sesudah lahir (resusitasi tidak steril, BBLR, ruang perawatan tidak 
memadai), dan infeksi lokal seperti stomatitis dan luka lecet. Penelitian oleh Ningsih (2016) hasil penelitian menunjukkan bahwa terdapat hubungan antara KPD dengan kejadian sepsis neonatus di Blud RS Benyamin Guluh Kabupaten Kolaka.

Sebesar 40\%,sepsis neonatorum sebagai salah satu bentuk penyakit infeksi pada bayi baru lahir masih merupakan masalah utama yang belum dapat terpecahkan sampai saat ini, sepsis neonatorum diperberat jika ibu mengalami ketuban pecah dini (KPD), dinyatakan bahwa 72 \% bayi sepsis berasal dari ibu hamil dengan ketuban pecah dini (KPD), ketuban pecah dini juga merupakan faktor risiko sepsis neonatorum menjadi 8,16 kali lebih besar, dan sebanyak 8-10\% wanita hamil pada usia kehamilan aterm mengalami ketuban pecah dini dan sebanyak 1-2\% pada usaia kehamilan prematur yang merupakan penyumbang utama kejadian sepsis neonatorum dan kematian perinatal (Sari, 2016)

Penularan infeksi ibu ke bayi dapat terjadi dalam rahim (bawaan), pada dan sekitar waktu pengiriman (perinatal) atau selanjutnya (postnatal) seperti yang diilustrasikan oleh transmisi organisme dengan menyusui. Infeksi maternal menyebar ke embrio dan janin dengan: (1) Menurunnya infeksi dari vagina bagian atas melalui serviks uterus ke cairan ketuban atau oleh (2) Penyebaran hematogen akibat viremia ibu, bakteremia atau parasitemia (WHO, 2017).

Sejalan dengan penelitian Ibrahim Khalesi (2017). Hasil penlitian menunjukkan hubungan yang signifikan terdeteksi antara terjadinya ISK pada neonatus dan ISK ibu, sehingga prevalensi keseluruhan ISK di antara neonatus ibu yang terkena secara signifikan lebih tinggi daripada yang diamati di antara ibu yang tidak terinfeksi. ISK ibu menghasilkan 5,9 kali lipat peningkatan risiko ISK neonatal. Dengan etiologi bakteri yang paling umum adalah Escherichia coli $(65,9 \%)$, diikuti oleh Klebsiella (14,6\%) dan Staphylococci $(9,8 \%)$.

Selain faktor ibu juga terdapat faktor bayi yang dapat berhubungan dengan kejadian sepsis pada neonatorum. Penelitian oleh Jaya (2019) dengan hasil penelitian menunjukkan 23 sampel (46\%) prematur dan 27 sampel (54\%) tidak prematur, dari 50 sampel sebanyak 20 sampel yang mengalami sepsis neonatorum. Dari hasil uji hipotesis dengan menggunakan uji chi square didapatkan nilai $p$ sebesar 0,005, dan risiko prevalens sebesar 2,73. Dapat disimpulkan Prematuritas secara signifikan berhubungan dengan kejadian sepsis neonatorum yang dirawat di ruang Perinatologi dan NICU RSUD Wangaya Kota Denpasar.

Kematian neonatus di Lampung pada tahun 2017 tertinggi terjadi di Bandar Lampung yaitu berjumlah 166 kasus $(18,51 \%)$ atau sebanyak 148 kasus (89\%) kematian pada masa perinatal dini dan sebanyak 18 kasus (11\%) kematian pada masa perinatal lanjut. Kematian neonatal di Provinsi Lampung $L$ pada tahun 2018 yang tertinggi disebabkan oleh BBLR yaitu sebesar 69 kasus $(41,57 \%)$, kemudian penyebab lainnya adalah Asfiksia 64 kasus $(38,55 \%)$, infeksi 4 kasus $(2,41 \%)$, kelainan konginetal 5 kasus (3,01\%), dan lain-lain sebanyak 24 kasus (14,46\%) (Dinkes Kota Bandar Lampung, 2018).

Penelitian yang dilakukan Apriliana ditemukan bahwa kejadian sepsis neonatorum di Lampung tepatnya di RSUD Dr H Abdul Moeloek Lampung, angka kejadian sepsis pada tahun 2009 adalah sebesar $30.1 \%$ dengan angka kematian 40\% (Apriliana, 2013). Data Rekam medis dari tahun 2017 - 2019 terlihat peningkatan kejadian sepsis 
Neonatorum di Rumah Sakit Umum Daerah (RSUD) Dr. H. Abdul Moeloek, dimana tahun 2017 terdapat 193 kejadian, di tahun 2018 terdapat 242 kejadian dan di tahun 2019 terdapat 317 kejadian sepsis neonatorum. Berdasarkan angka kejadian tersebut, terlihat bahwa kejadian sepsis menjadi salah satu permasalahan yang terjadi di RS tersebut.

Rumah Sakit Umum Daerah (RSUD) Dr. H. Abdul Moeloek merupakan rumah sakit rujukan provinsi tipe $B$ di Provinsi Lampung dimana kejadian ini dapat menjadi preferensi kejadian sepsis yang ada di Lampung. Berdasarkan data diketahui bahwa di tahun 2017 kejadian infeksi saat hamil sebanyak 25 kasus, KPD sebanyak 410 kasus, dan kasus BBLR sebesar 264. Di tahun 2018 kejadian infeksi saat hamil sebanyak 28 kasus, KPD sebanyak 357 kasus, dan kasus BBLR sebesar 353. Di tahun 2019 kejadian infeksi saat hamil sebanyak 35 kasus, KPD sebanyak 219 kasus, dan kasus BBLR sebesar 304.

Berdasarkan data presurvey, pada tahun 2017 di RSUD Dr. H. Abdul Moeloek Provinsi Lampung terdapat kasus sepsis neonatorum sebanyak 86 bayi $(6,5 \%)$ dari 1.325 bayi yang dirawat di ruang Perinatologi Pada tahun 2018 di RSUD Dr. H. Abdul Moeloek Provinsi Lampung terdapat kasus sepsis neonatorum sebanyak 107 bayi $(7,6 \%)$ dari 1.408 bayi yang dirawat di ruang
Perinatologi. (Rekam medik RSUD Dr. H. Abdul Moeloek Provinsi Lampung 2018)

Berdasarkan fenomena tersebut, maka penulis tertarik untuk melakukan penelitian lebih lanjut terkait masalah di atas dengan judul "Analisis FaktorFaktor Yang Berhubungan Dengan Kejadian Sepsis Neonatorum Di Ruang Perinatologi RSUD Dr. H. Abdul Moeloek Provinsi Lampung tahun 2020"

\section{METODE PENELITIAN}

Jenis penelitian analitik kuantitatif dengan pendekatan cross sectional, diketahui faktor-faktor yang berhubungan dengan kejadian Sepsis Neonatorum, yang di lakukan telah dilaksanakan bulan Agustus tahun 2020. subjek dalam penelitian ini adalah seluruh bayi yang lahir di tahun 2019 di RSUD Dr. H. Abdul Moeloek Provinsi Lampung tahun 2020. Obyek dalam penelitian ini adalah kejadian Sepsis Neonatorum. Analisis data dengan analisis univariat dan analisis bivariat (chi square). Pada penelitian ini teknik pengumpulan data yaitu dengan menggunakan lembar observasi yaitu dilakukan dengan pengukuran dari rekam medik untuk mengetahui KPD, BBLR, Infeksi saat hamil dan kejadian Sepsis Neonatorum. Dan telah dilakukan uji etik No. 1149/EC/KEPPUNMAL/VIII/2020. 
HASIL PENELITIAN DAN PEMBAHASAN

Analisis Univariat

Distribusi frekuensi Sepsis Neonatorum, ketuban pecah dini, infeksi saat hamil dan BBLR

\begin{tabular}{clrr}
\hline Variabel & \multicolumn{1}{c}{ Kategori } & Frekuensi & Persentase (\%) \\
\hline \multirow{2}{*}{ Sepsis neonatorum } & Sepsis neonatorum & 34 & 19,1 \\
\cline { 2 - 4 } & Tidak Sepsis neonatorum & 144 & 80,9 \\
\hline & Total & 178 & 100,0 \\
\hline
\end{tabular}

Berdasarkan tabel 1 diketahui bahwa

besar responden Tidak Sepsis dari 178 responden, pada sebagian neonatorum sebanyak $144(80,9 \%)$

Distribusi Frekuensi ketuban pecah dini di ruang Perinatologi RSUD Dr. H. Abdul Moeloek Provinsi Lampung tahun

\begin{tabular}{crrr}
\hline Variabel & Kategori & Frekuensi & Persentase (\%) \\
\hline Ketuban Pecah dini & KPD & 65 & 36,5 \\
\cline { 2 - 4 } & Tidak KPD & 113 & 63,5 \\
\hline & Total & 178 & 100,0 \\
\hline
\end{tabular}

Berdasarkan tabel 2 diketahui bahwa dari 178 responden, sebagian besar

responden Tidak KPD sebanyak 113 $(63,5 \%)$

Distribusi Frekuensi infeksi saat hamil di ruang Perinatologi RSUD Dr. H. Abdul Moeloek Provinsi Lampung

\begin{tabular}{ccrr}
\hline Variabel & Kategori & Frekuensi & Persentase (\%) \\
\hline \multirow{2}{*}{ Infeksi saat kehamilan } & Ada infeksi & 20 & 11,2 \\
\cline { 2 - 4 } & tidak ada infeksi & 158 & 88,8 \\
\hline \multicolumn{2}{c}{ Total } & 178 & 100,0 \\
\hline
\end{tabular}

Berdasarkan tabel 3 diketahui bahwa dari 178 responden, sebagian besar responden tidak ada infeksi sebanyak $158(88,8 \%)$.

Distribusi Frekuensi BBLR di ruang Perinatologi RSUD Dr. H. Abdul Moeloek Provinsi Lampung

\begin{tabular}{|c|c|c|c|c|}
\hline \multicolumn{2}{|c|}{ Variabel } & Kategori & Frekuensi & Persentase (\%) \\
\hline \multirow{2}{*}{$\begin{array}{ll}\text { Berat Badar } \\
\text { Rendah (BBLR) }\end{array}$} & \multirow[t]{2}{*}{ Lahir } & BBLR & 99 & 55,6 \\
\hline & & Tidak BBLR & 79 & 44,4 \\
\hline \multicolumn{3}{|c|}{ Total } & 178 & 100,0 \\
\hline
\end{tabular}

Berdasarkan tabel 4 diketahui bahwa dari 178 responden, Sebagian besar responden BBLR sebanyak 99 (55,6\%). 
Analisis Bivariat

Hubungan ketuban pecah dini dengan Sepsis Neonatorum di ruang Perinatologi RSUD Dr. H. Abdul Moeloek Provinsi Lampung

\begin{tabular}{|c|c|c|c|c|c|c|c|c|}
\hline \multirow{3}{*}{$\begin{array}{l}\text { Ketuban } \\
\text { Pecah Dini }\end{array}$} & \multicolumn{4}{|c|}{ Sepsis neonatorum } & \multirow{3}{*}{$\mathrm{N}$} & \multirow{3}{*}{$\%$} & \multirow{3}{*}{$\begin{array}{c}p- \\
\text { value }\end{array}$} & \multirow{3}{*}{$\begin{array}{c}\text { OR } \\
95 \% \mathrm{Cl}\end{array}$} \\
\hline & \multicolumn{2}{|c|}{$\begin{array}{c}\text { Sepsis } \\
\text { neonatorum }\end{array}$} & \multicolumn{2}{|c|}{$\begin{array}{l}\text { Tidak Sepsis } \\
\text { neonatorum }\end{array}$} & & & & \\
\hline & $\mathrm{n}$ & $\%$ & $\mathrm{n}$ & $\%$ & & & & \\
\hline KPD & 29 & 44,6 & 36 & 55,4 & 65 & 100,0 & & 17,400 \\
\hline Tidak KPD & 5 & 4,4 & 108 & 95,6 & 113 & 100,0 & 0,000 & $\begin{array}{l}(6,266- \\
48,316)\end{array}$ \\
\hline
\end{tabular}

Berdasarkan Tabel 5 Hasil uji statistik diperoleh $p$-value $=0,000$ yang berarti $p<a(0,05)$, maka dapat disimpulkan bahwa terdapat hubungan ketuban pecah dini dengan sepsis neonatorum di ruang Perinatologi RSUD Dr. H. Abdul Moeloek Provinsi Lampung tahun 2020, dengan nilai OR 17,400 artinya responden dengan KPD memiliki risiko 17 kali lebih besar terjadi sepsis neonatorum jika dibandingkan dengan responden tidak KPD

Hubungan infeksi saat hamil dengan Sepsis Neonatorum di ruang Perinatologi RSUD Dr. H. Abdul Moeloek Provinsi Lampung

\begin{tabular}{|c|c|c|c|c|c|c|c|c|}
\hline \multirow{3}{*}{ Infeksi } & \multicolumn{4}{|c|}{ Sepsis neonatorum } & \multirow{3}{*}{$\mathrm{N}$} & \multirow{3}{*}{$\%$} & \multirow{3}{*}{$\begin{array}{c}p- \\
\text { value }\end{array}$} & \multirow{3}{*}{$\begin{array}{c}\text { OR } \\
95 \% \mathrm{Cl}\end{array}$} \\
\hline & \multicolumn{2}{|c|}{$\begin{array}{c}\text { Sepsis } \\
\text { neonatorum }\end{array}$} & \multicolumn{2}{|c|}{$\begin{array}{l}\text { Tidak Sepsis } \\
\text { neonatorum }\end{array}$} & & & & \\
\hline & $\mathrm{n}$ & $\%$ & $\mathrm{n}$ & $\%$ & & & & \\
\hline Ada Infeksi & 10 & 50,0 & 10 & 50,0 & 20 & 100,0 & & 5,583 \\
\hline $\begin{array}{l}\text { Tidak Ada } \\
\text { Infeksi }\end{array}$ & 24 & 15,2 & 134 & 84,8 & 158 & 100,0 & 0,001 & $\begin{array}{l}(2,099- \\
14,851)\end{array}$ \\
\hline
\end{tabular}

Berdasarkan Tabel 6 Hasil uji statistik diperoleh $p$-value $=0,001$ yang berarti $p<a(0,05)$, maka dapat disimpulkan bahwa ada hubungan infeksi saat hamil dengan sepsis neonatorum di ruang Perinatologi RSUD Dr. H. Abdul Moeloek Provinsi Lampung tahun 2020, dengan nilai OR 5,583 artinya responden yang mengalami infeksi saat hamil memiliki resiko 5 kali labih besar terjadi sepsis neonatorum jika dibandingkan dengan responden tidak ada infeksi saat hamil. 
Hubungan BBLR dengan Sepsis Neonatorum di ruang Perinatologi RSUD Dr. H. Abdul Moeloek Provinsi Lampung

\begin{tabular}{|c|c|c|c|c|c|c|c|c|}
\hline \multirow{3}{*}{ BBLR } & \multicolumn{4}{|c|}{ Sepsis neonatorum } & \multirow{3}{*}{$\mathrm{N}$} & \multirow{3}{*}{$\%$} & \multirow{3}{*}{$\begin{array}{c}p- \\
\text { value }\end{array}$} & \multirow{3}{*}{$\begin{array}{c}\text { OR } \\
95 \% \mathrm{Cl}\end{array}$} \\
\hline & \multicolumn{2}{|c|}{$\begin{array}{c}\text { Sepsis } \\
\text { neonatorum }\end{array}$} & \multicolumn{2}{|c|}{$\begin{array}{l}\text { Tidak Sepsis } \\
\text { neonatorum }\end{array}$} & & & & \\
\hline & $\mathrm{N}$ & $\%$ & $\mathrm{n}$ & $\%$ & & & & \\
\hline BBLR & 27 & 27,3 & 72 & 72,7 & 99 & 100,0 & & 3,857 \\
\hline Tidak BBLR & 7 & 8,9 & 72 & 91,1 & 79 & 100,0 & 0,004 & $\begin{array}{c}(1,579- \\
9,423)\end{array}$ \\
\hline
\end{tabular}

Berdasarkan Tabel 6 Hasil uji statistik diperoleh $p$-value $=0,000$ yang berarti $p<a(0,05)$, maka dapat disimpulkan bahwa ada hubungan BBLR dengan sepsis neonatorum di ruang Perinatologi RSUD Dr. H. Abdul

\section{PEMBAHASAN}

Hubungan ketuban pecah dini dengan Sepsis Neonatorum di ruang Perinatologi RSUD Dr. H. Abdul Moeloek Provinsi Lampung tahun 2020

Hasil uji statistik diperoleh $p$-value $=$ 0,000 yang berarti $p<a(0,05)$, maka dapat disimpulkan bahwa terdapat hubungan ketuban pecah dini dengan Sepsis Neonatorum di ruang Perinatologi RSUD Dr. $\mathrm{H}$. Abdul Moeloek Provinsi Lampung tahun 2020, dengan nilai OR 17,400 artinya responden dengan KPD memiliki peluang 17 kali dengan Sepsis neonatorum jika dibandingkan dengan responden Tidak KPD

Ketuban pecah dini (KPD) adalah pecahnya ketuban sebelum waktunya melahirkan atau sebelum terdapat tanda prtsalinan, dan ditunggu satu jam belum dimulainya tanda persalinan. Waktu sejak ketuban pecah sampai terjadi kontraksi rahim disebut "kejadian ketuban pecah dini (periode laten)” (Manuaba, 2014). Ketuban pecah dini (KPD) didefinisikan
Moeloek Provinsi Lampung tahun 2020, dengan nilai OR 3,857 artinya responden dengan BBLR memiliki resiko 3 kali lebih besar mengalami sepsis neonatorum jika dibandingkan dengan responden tidak BBLR.

sebagai pecahnya ketuban sebelum waktunya melahirkan. Hal ini dapat terjadi pada akhir kehamilan maupun terjadi jauh sebelum waktunya melahirkan (Norma, 2013). Dikatakan ketuban pecah dini yaitu ketuban pecah sebelum persalinan berlangsung karena selaput membrane atau tekanan uterin atau kedua faktor tersebut. Juga karena infeksi yang berasal dari servik dan vagina (Asrinah at al, 2014).

Penelitian oleh Triswara (2018) dengan judul Hubungan Faktor Risiko Ibu Dan Janin Terhadap Kejadian Sepsis Neonatorum Di Ruang Perinatologi RSUD Dr. H. Abdul Moelok Provinsi Lampung. Hasil penelitian menunjukan mikroorganisme penyebab sepsis neonatorum adalah Pseudomonas sp (62,5\%), Klebsiella sp (25\%) dan Staphylococcus sp (12,5\%). Uji statistik didapatkan lama ketuban pecah dini $(p=0,002)$, usia kehamilan $(p=0,036)$, proses persalinan $(p=$ $0,006)$, berat bayi lahir rendah $(\mathrm{p}=$ $0,030)$ dan skor APGAR ( $p=0,002)$ dengan sepsis neonatorum. Dengan 
kesimpulan lama ketuban pecah dini lebih dari 18 jam, prematuritas, proses persalinan sesar, berat bayi lahir rendah dan skor APGAR merupakan faktor yang berpengaruh terhadap sepsis neonatorum.

Penelitian Indrawarman (2014) Terdapat 231 neonatus yang dilibatkan, terdiri dari 77 neonatus dengan sepsis dan 154 neonatus tanpa sepsis. Dari 77 neonatus dengan sepsis terdapat 56 neonatus dengan KPD dan dari 154 neonatus tanpa sepsis terdapat 75 neonatus dengan KPD. Dari hasil analisis Chi-Square didapatkan p 0.001, dan nilai OR 2.809 $(95 \% \mathrm{Cl} 1.553 ; 5.081)$. Kesimpulan : Terdapat hubungan antara KPD dengan terjadinya sepsis neonatorum. KPD meningkatkan risiko sebesar 2 kali pada neonatus untuk mengalami sepsis daripada yang tidak KPD.

Insiden ketuban pecah dini lebih tinggi pada wanita dengan malpresentasi janin, kehamilan kembar, dan hubungan yang signifikan antara lain keletihan karena pekerjaan dan paritas ibu. Selaput ketuban sangat kuat pada kehamilan muda. Pada trimester ketiga selaput ketuban mudah pecah. Melemahnya kekuatan selaput ketuban ada hubungannya dengan pembesaran uterus, kontraksi rahim dan gerakan janin. Pada trimester terahir terjadi perubahan biokimia pada selaput ketuban. Pecahnya ketuban pada kehamilan aterm merupakan hal fisiologis. Ketuban pecah dini pada kehamilan prematur disebabkan oleh adanya faktor - faktor eksternal, misalnya infeksi yang menjalar dari vagina. Ketuban pecah dini prematur sering terjadi pada polihdramnion, inkompeten serviks dan solusio plasenta (Manuaba, 2014).

Hasil penelitian ini juga sesuai dengan teori yang menyatakan bahwa ketuban pecah dini (KPD). berisiko tinggi mengalami infeksi atau sepsis neonatorum. KPD merupakan faktor risiko terjadinya sepsis neonatorum, hal ini dapat terjadi karena KPD dapat meningkatkan komplikasi kehamilan pada ibu dan bayi terutama infeksi. Bagi janin kurang bulan dengan KPD, risiko yang disebabkan kelahiran kurang bulan harus dibandingkan dengan risiko infeksi dan sepsis, yang keberadaannya di dalam rahim, bahkan dapat menjadikannya lebih problematik. Ditemukannya bakteri dengan pewarnaan gram atau biakan cairan amnion yang diperoleh pada amniosentesis berkorelasi dengan infeksi ibu berikutnya pada sekitar 50 persen kasus dan sepsis neonatal pada sekitar 25 persen. (Negara, 2016).

Hasil penelitian di dapatkan dari 65 responden yang KPD terdapat 36 $(55,4 \%)$ tidak terjadi sepsis neonatorum, hal ini di sebabkan responden KPD cepat di lakukan penanganan yang tepat di perhatikan kesterilan alat dan ibu serta tenaga kesehatan sehingga bayi sehat.

Sepsis neonatorum sering dihubungkan dengan ketuban pecah dini karena infeksi dengan ketuban pecah dini saling mempengaruhi. Infeksi genetalia bawah pada ibu hamil dapat menyebabkan ketuban pecah dini, demikian pula ketuban pecah dini dapat memudahkan infeksi ascendens pada bayi. Sepsis neonatorum sering dihubungkan dengan infeksi intra natal dan infeksi postnatal terutama nosokomial.

Berdasarkan hasil penelitian di dapatkan dari 113 responden tidak KPD di dapatkan 5 (4,4\%) dengan kejadian sepsis neonatorum, hal ini di sebabkan oleh banyak faktor, karena faktor penyebab sepsis neonatorum tidak hanya KPD dapat terjaid karena 
bayi itu sendiri seperti BBLR, kemudian infeksi ibu atau jalan lahir.

Menurut peneliti bahwa pada bayi yang lahir dengan riwayat ketuban pecah dini rawan terjadinya infeksi bakteri pada masa neonatal. Sedangkan infeksi bakteri sendiri merupakan salah satu penyebab dari sepsis neonatorum, menurut Haque KN sepsis merupakan suatu proses berkelanjutan mulai dari infeksi, Systemic Inflammatory Response Syndrome (SIRS), sepsis, sepsis berat, renjatan/syok septik, disfungsi multiorgan, dan akhirnya kematian.

\section{Hubungan infeksi saat hamil dengan sepsis neonatorum di ruang Perinatologi RSUD Dr. H. Abdul Moeloek Provinsi Lampung tahun 2020}

Hasil uji statistik diperoleh $p$-value $=$ 0,001 yang berarti $p<\alpha(0,05)$, maka dapat disimpulkan bahwa ada hubungan infeksi saat hamil dengan Sepsis Neonatorum di ruang Perinatologi RSUD Dr. $\mathrm{H}$. Abdul Moeloek Provinsi Lampung tahun 2020, dengan nilai OR 5,583 artinya responden dengan infeksi saat hamil memiliki peluang 5 kali Sepsis neonatorum jika dibandingkan dengan responden tidak ada infeksi saat hamil

Terdapat 3 mekanisme terjadinya infeksi pada neonatus yaitu saat neonatus dalam kandungan (pranatal), saat persalinan (intranatal) dan setelah lahir (pasca natal). Paparan infeksi pranatal terjadi secara hematogen dari ibu yang menderita penyakit tertentu, seperti infeksi virus atau infeksi parasit Toxoplasma, Rubella, Cytomegalovirus, Herpes (TORCH) dimana transmisi secara hematogen melalui plasenta ke janin. Infeksi tersebut dapat menyebabkan aborsi spontan dini, malformasi kongenital, pertumbuhan terhambat intrauterin, bayi lahir prematur, penyakit akut selama masa neonatal atau infeksi persisten dengan sekuele. Selama dalam kandungan janin terlindungi dari paparan bakteri ibu oleh adanya cairan dan lapisan amnion. Namun bila terjadi kerusakan lapisan amnion, janin berisiko menderita infeksi melalui amnionitis. Ig M dan Ig A merupakan imunoglobulin pertama yang dibentuk fetus sebagai respon dari infeksi bakteri gram negatif intrauterine. Ig $M$ dibentuk pada usia kehamilan 10 minggu dimana kadarnya rendah saat lahir dan meningkat saat terjadi paparan infeksi selama kehamilan.

Penelitian oleh Sari (2016) dengan judul Faktor-faktor yang Berhubungan dengan Kejadian Sepsis pada Neonatorum di Rumah Sakit Moehammad Hoesin Palembang. Hasil penelitian dari uji Chi Square didapatkan ada hubungan yang bermakna antara kejadian sepsis neonatorum dengan ketuban pecah dini (KPD), status paritas ibu yang tinggi, jenis kelamin bayi, tingkat maturitas, dan tidak ada hubungan ibu yang menderita diabetes mellitus dengan kejadian sepsis pada neonatorum di Rumah Sakit Mohammad Hoesin Palembang Tahun 2012. Hasil penelitian ini diharapkan dapat bermanfaat sebagai informasi mengenai penyakit infeksi sepsis neonatorum.

Hasil penelitian Wilar (2016) Di antara 72 kasus dengan faktor risiko sepsis, $58(80,6 \%)$ bayi di antaranya secara klinis, laboratorium, dan faktor risiko dinyatakan positif sepsis. Sepsis juga didiagnosis apabila terdapat respons sistemik terhadap infeksi tertentu.4 Sepsis banyak ditemukan pada bayi kecil terutama prematur yang mempunyai manifestasi klinis sering tidak jelas.8 Sepsis dapat 
mencakup beberapa infeksi sistemik neonatus seperti meningitis, pneumonia, osteomielitis artritis dan ISK. Pada bayi dengan sepsis terjadi imunosupresi sehingga tubuh tidak mampu untuk mengatasi infeksi sehingga dapat terjadi infeksi nosokomial.

Karakteristik ibu dan janin yang berhubungan dengan SAD telah sering diteliti. Faktor ibu meliputi demam intrapartum $>37,50 \quad \mathrm{C}$, korioamnionitis, dan KPD $>18$ jam. Faktor risiko neonatus meliputi usia gestasi 18 jam yang merupakan salah satu dari faktor risiko mayor yang berhubungan signifikan dengan sepsis (Liwaha, 2014).

Hasil penelitian di dapatkan dari 20 responden dengan infeksi ibu saat hamil di dapatkan 10 bayi tidak mengalami sepsis neonatorum, dan dari 158 ribu tidak memiliki infeksi sebanyak 24 terjadi sepsis neonatorum. Salah satu infeksi yang cukup banyak terjadi pada kehamilan adalah infeksi saluran kemih. Disebutkan karena perubahan anatomi dan fungsional dari kehamilan dapat meningkatkan risiko infeksi saluran kemih, sekitar 2 sampai 7\% wanita hamil didapatkan bakteriuria asimptomatik, bakteri yang ditemukan sebagian besar adalah Escherichia coli. Wanita hamil dengan bakteriuria asimptomatik bila tidak diterapi dengan tepat dapat berkembang menjadi bakteriuria yang simptomatik atau disebut dengan infeksi saluran kemih.

Menurut peneliti bahwa ibu dengan infeksi saat hamil tidak selalu mengakibatkan sepsis neonatorum karena jenis persalinan juga mempengaruhi penularan bakteri yang ada di jalan lahir, dari hasil dokumen jenis persalinan di dapatkan 3 responden degan secsio sesaria pada ibu dengan infeksi tetapi bayi tidak sepsis neonatorum.

Kejadian sepsis dipengaruhi oleh berbagai faktor seperti faktor ibu (kelahiran kurang bulan, persalinan dengan tindakan, demam pada ibu), faktor lingkungan, serta yang paling penting faktor dari neonatus sendiri, seperti jenis kelamin, status kembar, prosedur invasif, bayi kurang bulan dan berat badan lahir. Faktor risiko terjadinya sepsis adalah bayi dengan jenis kelamin laki-laki, karena aktivitas pada bayi laki-laki lebih tinggi dibandingkan bayi perempuan sehingga bayi laki-laki memerlukan oksigen yang lebih banyak, karena jika oksigen kurang di dalam tubuh maka bakteri anaerob akan mudah berkembang.

Menurut peneliti Sebagian besar komplikasi obstetrik pre dan intrapartum berhubungan dengan peningkatan risiko infeksi pada neonatus di antaranya kehamilan kurang bulan, KPD, inersia uteri dengan ekstrasi forcep tinggi, dan demam intrapartum. Infeksi yang bermanifestasi pada awal minggu pertama kehidupan pada umumnya berhubungan dengan mikroorganisme yang ditularkan dari ibu kepada janinnya dan memiliki epidemiologi yang berbeda dengan infeksi yang didapat setelah periode neonatus.

Hubungan BBLR dengan Sepsis Neonatorum di ruang Perinatologi RSUD Dr. H. Abdul Moeloek Provinsi Lampung tahun 2020

Hasil uji statistik diperoleh $p$-value = 0,000 yang berarti $p<\alpha(0,05)$, maka dapat disimpulkan bahwa ada hubungan BBLR dengan Sepsis Neonatorum di ruang Perinatologi RSUD Dr. H. Abdul Moeloek Provinsi Lampung tahun 2020, dengan nilai OR 3,857 artinya responden dengan BBLR 
memiliki peluang 3kali Sepsis neonatorum jika dibandingkan dengan responden Tidak BBLR

BBLR adalah bayi dengan berat lahir kurang dari 2500 gram tanpa memandang masa gestasi. Berat lahir rendah adalah berat bayi yang ditimbang dalam 1 jam setelah lahir. Berat badan merupakan salah satu indikator kesehatan Bayi Baru Lahir (BBL). Rata-rata berat badan normal (usia gestasi 37s.d 41 minggu) adalah 3200 gram. Secara umum, Bayi Berat Lahir Rendah (BBLR) lebih besar resikonya untuk mengalami masalah atau komplikasi pada saat lahir (Damanik, 2010).

Bakteri penyebab sepsis neonatorum yang terdapat pada jalan lahir saat takikardi (>100 x/menit), takikardi janin (>160 x/menit), nyeri pada uterus dan atau terdapat cairan amnion berbau busuk. Ketuban pecah dini juga akan mengakibatkan infeksi chorioamnionitis. Umumnya diagnosis klinis untuk infeksi bakteri saat ibu hamil atau chorioamnionitis adalah demam pada ibu $>38^{\circ} \mathrm{C}$ dan terdapat dua tanda dari: leukositosis (> 15000 $\mathrm{sel} / \mathrm{mm}$ ).

BBLR dengan Berat $<2500$ gram cenderung mudah mengalami komplikasi seperti hipotermi, pemberian minum, gangguan nafas juga infeksi (Kemenkes RI, 2011). Hal ini juga sesuai dengan terori yang menyatakan bahwa semakin kecil berat bayi lahir rendah semakin tinggi kemungkinan memiliki komplikasi dan akan semakin buruk prognosisnya (Mochtar, 2012).

Penelitian oleh Ningsih (2016) dengan judul Hubungan BBLR, KPD dan persalinan prematur dengan kejadian sepsis neonatus di Blud RS Benyamin Guluh Kabupaten Kolaka. Hasil penelitian menggunakan analisis Chi Square menunjukkan bahwa terdapat hubungan antara KPD dengan kejadian sepsis neonatus $(P$ value $(0.006)<a)$. Kesimpulan yang didapatkan terdapat hubungan antara KPD dengan kejadian sepsis neonatus.

Tanda dan gejala dari sepsis neonatorum berupa tanda dan gejala umum seperti hipertermia atau hipotermi bahkan normal, aktivitas lemah atau tidak tampak sakit, berat badan menurun tiba-tiba, terdapatnya tanda dan gejala gangguan saluran pernapasan seperti dispnea, takipnea, apnea, tampak tarikan otot pernapasan, merintih, mengorok, dan pernapasan cuping hidung Neonatus memiliki risiko sepsis bila memenuhi dua kriteria risiko mayor atau satu kriteria risiko mayor ditambah dua kriteria minor. Bayi didiagnosis sepsis berdasarkan adanya gejala klinik seperti letargi, reflek hisap menurun, merintih, iritabel, kejang, terdapat gangguan kardiovaskuler, gangguan hematolitik, gangguan gastrointestinal, gangguan respirasi waktu pengosongan lambung memanjang dan pemeriksaan laboratorium seperti CRP $>10 \mathrm{mg} / \mathrm{L}$, IT ratio $\geq 0,25$, leukosit $30.000 / \mu \mathrm{L}$ dengan atau tanpa biakan darah positip (Wilar, 2010)

Menurut Rahmawati (2018) Pada bayi BBLR terutama dengan prematuritas pematangan organ tubuhnya (hati, paru, enzim, pencernaan, otak, daya pertahanan tubuh terhadap infeksi) belum sempurna, maka bayi BBLR sering mengalami komplikasi yang berakhir dengan kematian. Bayi yang lahir dengan berat badan normal akan mengalami penurunan berat badan pada minggu pertama setelah lahir, namun akan mengalami peningkatan seiring dengan pertumbuhan bayi. Pada BBLR menurunnya berat badan bayi dapat terjadi setiap saat, karena 
biasanya akan ada masalah pada pemberian Air Susu Ibu (ASI), kurang atau tidak mampunyai bayi menghisap ASI juga menjadi risiko mudahnya terkena infeksi, hal ini disebabkan kurangnya nutrisi dan immunoglobulin yang didapat bayi dari ASI. Pada BBLR pusat pengaturan pernafasan belum sempurna, otot pernafasan dan tulang iga masih lemah yang mengakibatkan oksigen yang masuk ke otak kurang, jika oksigen kurang maka kuman anaerob mudah berkembang yang menyebabkan mudah terjadi infeksi.

Hasil penelitian di dapatkan bahwa dari 99 bayi dengan BLR di dapatkan 72 (72\%) bayi tidak sepsis neonatorum, hal ini di sebabkan daya tahan tubuh bayi, serta penanganan yang cepat dan tepat pada bayi sengan BBLR di rumah sakit akan memberikan efek yang sangat baik, dan bayi tidak terjadi sepsis neonatorum, jaga kehangatan bayi, menjaga kebersihan bayi dan alat penanganan pada bayi, akan menjauhkan bayi dari kejadian sepsis neonatorum.

Hasil penelitian di dapatkan bahwa dari 79 bayi tidak BBLR di dapatkan 7 bayi dengan kejadian sepsis neonatorum. Hal ini kembali pada faktor- faktor penyebab sepsis neonatorum yang memiliki banyak penyebab seperti jenis persalinan, keadaan infeksi ibu saat hamil, infeksi pada jalan lahir, dan masih banyak penyebab lainnya.

Menurut peneliti bayi yang lahir dengan berat badan kurang dari normal akan memiliki komplikasi lebih banyak di banding bayi dengan berat badan normal, antaranya lebih mudah terserang penyakit, virus dan bakteri, maka pada bayi BBLR akan lebih cepat terserang nya penyakit infeksi hingga dapat menyebabkan sepsis neounatorum.

\section{KESIMPULAN}

Diketahui bahwa dari 178 responden, sebanyak $144 \quad(80,9 \%)$ responden tidak Sepsis neonatorum, sebagian besar responden Tidak KPD sebanyak $113(63,5 \%)$, sebagian besar responden tidak ada infeksi sebanyak 158 (88,8\%). Sebagian besar responden BBLR sebanyak 99 (55,6\%). Ada hubungan ketuban pecah dini dengan Sepsis Neonatorum di ruang Perinatologi RSUD Dr. $\mathrm{H}$. Abdul Moeloek Provinsi Lampung tahun 2020, (p value 0,000 OR 17,400). Ada hubungan infeksi saat hamil dengan Sepsis Neonatorum di ruang Perinatologi RSUD Dr. H. Abdul Moeloek Provinsi Lampung tahun 2020, ( $p$ value 0,001 OR 5,583). Ada hubungan BBLR dengan Sepsis Neonatorum di ruang Perinatologi RSUD Dr. H. Abdul Moeloek Provinsi Lampung tahun 2020, ( $p$ value 0 ,0040R 3,857)

\section{Saran}

Bagi Mahasiswa: Sebagai salah satu referensi tambahan untuk penelitian selanjutnya dan informasi bagi penyusunan program di puskesmas serta menambah bahan bacaan dan referesnisi mengenai Sepsis Neonatorum. Menambah pengalaman dalam penelitian serta sebagai bahan untuk penerapan ilmu yang telah didapat selama perkuliahan, serta sebagai masukan bagi penelitian selanjutnya, serta referensi untuk penelitian selanjutnya. 


\section{DAFTAR PUSTAKA}

Achadi, (2019). Kematian Maternal dan Neonatal di Indonesia. https://www.kemkes.go.id/resourc es/download/infoterkini/rakerkesnas2019/SESI\%20I/Kelompok\%201/1Kematian-Maternal-dan-Neonataldi-Indonesia.pdf

Apriliana, E., Rukmono, P., Erdian, D. N., \& Tania, F. (2013). Bakteri penyebab sepsis neonatorum dan pola kepekaannya terhadap antibiotika. In Seminar Nasional Sains \& Teknologi V Lembaga Penelitian Universitas Lampung (pp. 583-591).

Asrinah, D., Sulistyorini, D., Muflihah, I., \& Sari, D. (2014). Asuhan Kebidanan Masa Kehamilan. Yogyakarta: Graha Ilmu.

Hastono, S. P. (2016). Analisis Data pada Bidang kesehatan (Cetakan 1). Jakarta: Rajawali Pres.

Ibrahim, K. (2017). Hubungan BBLR, KPD dan Persalinan Prematur dengan Kejadian Sepsis Neonatus Di Blud RS Benyamin Guluh Kabupaten Kolaka Tahun 2016. (Jurnal Ilmiah Mahasiswa Kesehatan Masyarakat), 1(3).

Jaya, I. G. A., Suryawan, I. W. B., \& Rahayu, P. P. (2019). Hubungan prematuritas dengan kejadian sepsis neonatorum yang dirawat di ruang perinatologi dan Neonatal Intensive Care Unit (NICU) RSUD Wangaya kota Denpasar. Intisari Sains Medis, 10(1), 18.

\begin{tabular}{|c|c|c|}
\hline Kemenkes & (2018). & Pelayanan \\
\hline Kesehatan & Neonatal & esensial \\
\hline Pedoman & Teknis & Pelayanan \\
\hline $\begin{array}{l}\text { Kesehatan } \\
\text { Jakarta. }\end{array}$ & Tingkat & Pertama. \\
\hline Kemenkes & 19) & Kesehatan \\
\hline $\begin{array}{l}\text { Republik } \\
\text { Jakarta. }\end{array}$ & & iun \\
\hline
\end{tabular}

Kemenkes, R. I. (2011). Pedoman nasional penanganan infeksi menular seksual. Jakarta: Kemenkes RI.

Kemenkes. (2018). Penyakit Infeksi Menular Seksual. http://www.yankes.kemkes.go.id/r ead-penyakit-infeksi-menularseksual-3675.html diakses pada tanggal 12/03/2020.

Kementrian Kesehatan Republik Indonesia. (2018). Upaya percepatan penurunan angka kematian ibu dan bayi baru lahir di Indonesia. Jakarta : Direktorat Jendral Bina Gizi dan KIA.

Manuaba, I. B. G., Manuaba, I. B. G. F., \& Manuaba, I. B. G. (2014). Ilmu Kebidanan, Penyakit Kandungan dan KB untuk Pendidikan Bidan. Jakarta: EGC, 421-424.

Mochtar R. (2012). Sinopsis Obstetri. Jakarta: EGC.

Ningsih (2016) Hubungan BBLR, KPD dan persalinan prematur dengan kejadian sepsis neonatus di BLUD RS Benyamin Guluh Kabupaten Kolaka. https://media.neliti.com/media/p ublications/ 186604-ID-hubunganbblr-kpd-dan-persalinanprematu.pdf

Norma, N., \& Dwi, M. (2013). Asuhan Kebidanan Patologi. Yogyakarta: Nuha Medika.

Notoatmodjo, S. (2012). Metode Penelitian. Jakarta: Rineka Cipta

Prawirohardjo,S., (2016). Ilmu Kebidanan. Jakarta: Yayasan Bina Pustaka Sarwono Prawirohardjo

Proverawati, A., \& Ismawati, C. (2010). BBLR (berat badan lahir rendah). Yogyakarta: Nuha Medika, 61.

Putra, P. J. (2016). Insiden dan faktorfaktor yang berhubungan dengan sepsis neonatus di RSUP Sanglah Denpasar. Sari pediatri, 14(3), 205-10. 
Rahmawati (2016) Hubungan Sepsis Neonatorum dengan Berat Badan Lahir pada Bayi di RSUP Dr. M. Djamil Padang.

http://jurnal.fk.unand.ac.id

RSUD DR. H. Abdul Moeloek Provinsi Lampung Data Rekam Medis 2019

Rukiyah. (2013). Asuhan kebidanan 4 (Patologi) bagian 2. Jakarta: CV. Trans Info Media.

Saifuddin, A. (2014). Buku Acuhan Nasional Pelayanan Kesehatan Maternal Neonatal. Jakarta

Sari, E. (2016). Faktor-faktor yang Berhubungan dengan Kejadian Sepsis pada Neonatorum di Rumah Sakit Moehammad Hoesin Palembang. In Prosiding Seminar Nasional \& Internasional (Vol. 1, No. 1).

Siswanto, S. (2014). Metodologi penelitian kesehatan dan kedokteran. Edisi Pertama, cetakan kedua. Yogyakarta: Bursa Ilmu, 213-227.

Sugiyono. (2018). Metode Penelitian Kuantitatif, Kualitatif, dan R\&D. Bandung: Alfabeta.

Suherlim, R. (2015). Karakteristik Penderita HIV pada Ibu Hamil di Klinik Prevention Mother to Child Transmission (PMTCT) Poli Kebidanan RSUP Sanglah Denpasar
Periode Juli 2013-Juni 2014. Jurnal Mahasiswa PSPD FK Universitas Tanjungpura, 1(3).

Sukarni, I. (2014). Patologi:

Kehamilan, Persalinan, Nifas, dan Neonatus Resiko Tinggi.

Triswara, R. (2018). Hubungan Faktor Risiko Ibu Dan Janin Terhadap Kejadian Sepsis Neonatorum Di Ruang Perinatologi Rsud Dr. $H$. Abdul Moelok Provinsi Lampung.

WHO. (2017). Sepsis. https://www.who.int/newsroom/fact-sheets/detail/sepsis

WHO. (2019). WHO Global Survey on Infection Prevention and Control (IPC) and Hand Hygiene. https://www. who.int/infectionprevention/campaigns/ipc-globalsurvey-2019/en/

Wibowo, A. (2014). Metodologi Penelitian Praktis.

Wilar, R., Kumalasari, E., Suryanto, D. Y., \& Gunawan, S. (2016). Faktor risiko sepsis awitan dini. Sari pediatri, 12(4), 265-9.

Yeyeh, R. A., \& Lia, Y. (2012). Asuhan neonatus bayi dan anak balita. Jakarta: TIM.

Yohana, Y \& Yesika. (2011). Kehamilan dan Persalinan. Jakarta: Garda Med 